\title{
BENJAMIN Populism and Global Justice: MCKEAN A Sibling Rivalry?
}

\begin{abstract}
As academic literatures and political demands, global justice and populism look like competing ways of diagnosing and addressing neoliberal inequality. But both misunderstand neoliberalism and consequently risk reinforcing rather than undermining it. Neoliberalism does not just break down political and social hierarchies, but also relies on and sustains them. Unless populists recognize this, they will find that assertions of sovereignty do more to reinforce neoliberalism and reproduce its hierarchies than to resist them. Recognizing neoliberalism as not simply corrosive of solidarity but also producing its own affective ties suggests that global justice advocates need to develop a critique of individual attitudes that egalitarian liberals have often seen as private and been hesitant to judge. In short, if either populism or global justice hope to take advantage of neoliberalism's failures to advance an egalitarian politics, they need to reckon more carefully with their own entanglement with neoliberalism's hopes and hierarchies.
\end{abstract}

Keywords: egalitarian liberalism; neoliberalism; pluralism; populism; sovereignty.

\section{A Tale of Two Orientations}

How can we best resist neoliberalism and the threat it poses to freedom and equality around the world? As academic literatures and political demands, global justice and populism seem to offer competing answers. If both offer moralized condemnations of global elites, they point to different ways of responding, offering competing diagnoses of why neoliberalism is a threat and what opportunities this political moment offers. In this paper, I take the measure of these responses, arguing that neither can guide effective action against neoliberalism as they are currently constituted. Both offer compelling explanations of many features of global politics, as I explain in the rest of this section, even as each looks misguided from the perspective of the other. However, once we recognize that neoliberalism is more than simply market fundamentalism, but in fact offers its own political theory of the state, the family, and the self, then crucial flaws in the politics of each approach become clearer. Whether it takes the form of a politics pitting a virtuous people against a corrupt elite or a politics of cosmopolitan concern, effective resistance must reckon with the ways neoliberalism has become woven into the fabric of our institutions and daily lives rather than standing entirely in opposition to them. 
So, here's one way of narrating our global political present: decades of neoliberal policies like austerity, financialization, and global supply chains have led to widening inequality within countries along with precarity for those at the bottom. That precarity was only deepened by the 2008 financial crisis, which had disastrous effects around the world. Yet far from undermining neoliberalism, the crisis only reinforced it. In the US and Europe, political elites responded by saving banks and bondholders at the expense of ordinary people. And they justified their actions using a technocratic logic that aspired to be above democratic contestation. As a result, we now see a wave of popular politics revolting against neoliberalism and expanding the space of democratic contestation, first with Occupy in the US, the indignados in Spain, and Syriza in Greece, but now, regrettably, with mostly rightwing movements taking the lead.

This is the story told by Chantal Mouffe, among others. Mouffe writes, 'When citizens go to vote they see no difference between the choices facing them. That has allowed the development of right-populism. Marine Le Pen speaks to the pain of the popular classes [...]' (Desmoulières 2017). ${ }^{1}$ Consistent with this story, Mouffe decries the 'demonization' of far-right, anti-immigrant parties and argues that it is 'necessary to recognize the democratic nucleus at the origin of many of their demands' (Mouffe, 2018: 22). Of course, Mouffe deplores the particular policies these parties promote, but in this story, they have a legitimate complaint against neoliberalism and are simply proposing the wrong solution to the right problem. As a result, Mouffe believes that these voters are ripe for conversion to the left 'if a different language is made available' and suggests that the success of egalitarian political programs depends on converting them (ibid.: 22).

From this perspective, demands for global distributive justice seem misguided. For one thing, global justice seems to require the working and middle classes of rich countries to renounce their precariously privileged positions in favor of providing more support to the world's very poorest. Indeed, one way of reading Christoph Lakner and Branko Milanovic's famous 'elephant chart' of global inequality is that the distributive story of the past few decades has been precisely the rise of the working and middle class in China at the expense of the working and middle classes of the US and Europe (Lakner and Milanovic, 2016). That may look reasonably fair from the perspective of global distributive justice, but it also seems guaranteed to provoke precisely the kind of resentful backlash that fuels really existing populist movements. Think of the major speech on trade that Donald Trump delivered during the 2016 presidential campaign,

1 See also James Seidelman and John Watkins, who bluntly declare, "The election of Donald Trump marked the end of neoliberalism as the dominant hegemonic bloc of our time' (2019). 
where he claimed, 'This wave of globalization has wiped out totally, totally, our middle class. It does not have to be this way' and denounced 'a leadership class that worships globalism over Americanism' (Trump, 2016). And it's not just the right that demonizes developing countries as the cause of economic problems in the US; Sen. Bernie Sanders has also often employed rhetoric that takes for granted that US and Chinese workers have conflicting interests. In one such tweet, Sanders writes, 'We must say to corporate America loud and clear: you can't continue sending our jobs to China while millions are looking for work' (2016).

This connects to the other way that demands for global justice seem misguided from a populist perspective - who is the agent of global justice? Populism centers on a people, usually national, who are oppressed, exploited, or silenced by a powerful, self-serving elite. Without a connection to a political subject of some kind, demands for global justice are apt to appear as coming from a technocratic elite - an impression reinforced by arguments that claim to be based on an objective reason that purports to stand outside politics or partisan interest. From the populist perspective, what's needed is precisely a reinvigorated popular sovereignty to contest rule by transnational neoliberal elites. Matteo Salvini, the leader of Italy's hardline anti-immigrant Northern League, simply equates these terms, saying, 'In Italy they use terms sovereigntist and populist in a pejorative way but I am extremely proud to be considered in this way, in the original meaning of the word' (Sanderson, 2019). Similarly, Mouffe argues that, under the neoliberal conditions of what she, following Colin Crouch (2004), calls 'post-democracy,' only left populism 'provides the adequate strategy to recover and deepen the ideals of equality and popular sovereignty that are constitutive of a democratic politics' $(2018,13)$. As a result of this emphasis on national popular sovereignty, intergovernmental organizations look deeply suspect; for similar reasons, immigration and open borders are often seen as threats - or, as we've seen with Mouffe, calls for immigration controls are sympathetically interpreted as misguided expressions of a fundamentally democratic demand for control. On this view, the best and maybe only way to defeat rightwing antiimmigrant invocations of popular sovereignty is through a left populism that invokes popular sovereignty to its own ends.

So that's one framework for interpreting contemporary politics: seeing it primarily as a populist backlash to neoliberal inequality and precarity - an unruly backlash with some unpleasant features, to be sure, but one that is much needed and probably even inevitable. But that's not the only story that we can tell about our global political moment. Let's consider things now from the perspective of the transnational popular movements demanding global justice and the academic literature that has developed to defend and rearticulate 
those demands. ${ }^{2}$ From this perspective, US and European populism and neoliberalism look to be as often allies as opponents. US and European populism can readily seem like a defense of the global petite bourgeoisie against the proletariat of the developing world or a way to set the working classes of different countries against each other, further entrenching neoliberalism. Then consider the actual policies purported populists have pursued in power. While rightwing populist candidates rhetorically bash the terms of global trade as unfair to national industries, they often deepen neoliberal austerity at home; while Donald Trump campaigned on protecting welfare state programs like Social Security, he proposed cutting their budgets as soon as he took office (Golshan, 2019). While populism always targets some elite, the elite in question only occasionally happens to be the wealthy who benefit from neoliberalism; Trump appointed the president of Goldman Sachs as his chief economic advisor. Instead, it is often those who are disadvantaged by neoliberalism and demand government support who are painted as corrupt parasites. When Poland's teachers went on strike to protest being paid less than supermarket cashiers, the deputy justice minister from the governing populist Law and Justice party said their picket line was 'just like the Wehrmacht' (Santora and Berendt, 2019; see also Gera, 2019). Meanwhile, Poland's prime minister Mateusz Morawiecki, the leader of Law and Justice, said in an interview, 'We have a problem with a part of the European political elite and with journalists, but not with the normal people. For example, 97 per cent of all foreign investors would come to us again' (Puhl, 2018). Despite their rhetorical assaults on free trade, the policies of populists in power have generally diverged less from the neoliberal status quo than their rhetoric would imply. For example, Trump's much vaunted renegotiation of NAFTA was more like a 'rebranding' effort than a serious revision of its terms (Kolhatkar, 2018). While Trump's fondness for tariffs as a policy tool make it clear he's no free trade ideologue, his deepest conviction about trade seems to be that powerful countries ought to be able to extract even more value from their trading partners, which does not pose much of a challenge to neoliberal inequality.

2 While the broadly analytic literature on global justice doesn't always name neoliberalism as its target, it has consistently taken its cues from social movements that have resisted the imposition of neoliberal policies. Samuel Moyn has shown how Charles Beitz's original work extending Rawlsian social justice arguments to the globe was developed in the context of his support for the New International Economic Order promoted by the Third World movement in the 1970s (2018, 146-172). Iris Marion Young's work on transnational responsibility for justice grew directly from her engagement with the student-led anti-sweatshop movement. And I think it's no coincidence that the whole global justice debate that became inescapable in journals like Philosophy \& Public Affairs 15 years ago came in the wake of the highly visible protests at the 1999 WTO Summit in Seattle, the 2000 IMF/World Bank meetings in Washington DC, and elsewhere (though that connection was somewhat obscured by the redirection of popular mobilization against the US invasion of Iraq). And the global justice movement has at least as good a claim as the populists on the Occupy movement, which drew much of its organizing principles and analytic framework from the grassroots global justice movement that pointedly opposed the elite-driven World Economic Forum in Davos with its own World Social Forum in Porto Alegre. 
From the perspective of global justice, the recurrent populist concern with immigration hardly looks like a badly expressed democratic concern. Rather, populist opposition to immigration looks unfair and unjustified. It's not only that refusing to admit poor immigrants has unjust distributive effects, but that the populists' appeal to national sovereignty looks ungrounded. From the perspective of global justice, sovereignty raises more philosophical questions than it answers: why should this group have the right to make such a decision without considering its effects on outsiders? What justifies this distinction between insiders and outsiders in the first place? Even when sovereignty rests on 'the people' in the most abstract sense - perhaps especially then - ethnicity or race often ends up giving substance to that dividing line in a plainly unjust way.

From the perspective of global justice, some populist ways of invoking sovereignty look like nothing so much as an attempted shield from normative evaluation. Consider Richard Tuck's argument for Lexit as an example. Like a lot of contemporary political diagnoses, its starting point is an observation about anxiety. In a piece Tuck co-authored with Christopher Bickerton, they argue that people were scared to learn that the UK was constrained from regulating immigration from EU member states. Tuck and Bickerton write,

'Though fear of this [constraint] was inevitably intertwined with hostility to immigration, the fact of powerlessness was real, and it presaged powerlessness in other areas in the future. This is the key thing Remainers, and especially Remainers on the Left, have to realize. Brexit is therefore above all about sovereignty' (2017: 9).

So, on this view (as on Mouffe's), the hostility to immigrants they concede to be part of the populist project is incidental to what really matters - sovereignty, which is seen as a necessary precondition to repoliticizing neoliberal markets and to exercising a democratic will. For Tuck, the only real tool that can address economic injustice is 'an omnicompetent democratic legislature...not constrained by a constitution' - that is, a sovereign body that is the ultimate authority and which is obliged to justify its actions to no one. (Tuck, 2016).

Tuck, like many left populists, sees unconstrained state sovereignty as essential to disrupting the global neoliberal economy. Neoliberalism is associated with open flows of capital, goods, and people so to the extent that the global justice literature promotes a cosmopolitan openness, it becomes a kind of useful idiot for neoliberalism. While global justice scholars often advocate for strong international institutions with the power to redistribute resources and regulate the economy, the practical political effect of endorsing such ideal institutions is to shore up the legitimacy of actually existing international institutions by 
suggesting that they are a step on the pathway to justice rather than what most people see them as: technocratic bureaucracies distant from ordinary people that serve the interests of the global elite. To the extent demands for global justice qualify and constrain sovereign powers, populists argue that they serve neoliberalism, even if their ostensible target is inequality. Openness is associated with a lack of control, which causes anxiety; that anxiety can be soothed by forcefully asserting sovereign power.

Trump echoes this way of talking about the global economy. In the same campaign speech where he bemoaned globalism for destroying the middle class, Trump praised Brexit as a political model, echoing the Leave campaign's motto by saying that 'Our friends in Britain recently voted to take back control of their economy, politics and borders' (Trump, 2016). From the perspective of global justice, such claims look extremely questionable. The sovereign state system is something that stands in need of justification, particularly in an interdependent world where policies in one place affect the economy and environment of others. Not only are normative judgments by outsiders of a people's immigration policy appropriate, but it is an open question whether or not peoples even have the right to exclude others.

Not all defenses of sovereignty align with the logic I'm tracing here. Many views of sovereignty do not invest 'the people' with ultimate control in the sense Tuck says they desire and deserve. Instead one might understand sovereignty as conditional; for example, one might argue that sovereignty must be compatible with human rights, in which case peoples do not have complete control over their borders but must show their respect for human rights by admitting refugees. Habermasian conceptions of sovereignty do not posit sovereignty as ultimate and unconstrained, but rather as dependent on reciprocal recognition in some sense; that means international law and international organizations can actually be constitutive for sovereignty in this sense. But that's a view which sees the EU as potentially bolstering sovereignty rightly understood while populist views like Tuck's see the EU as institutionalized neoliberalism; the entire value of sovereignty for him rests on its being unconstrained. The kind of sovereignty which ultimately expresses interdependence and mutual recognition can't deliver the feeling of unilateral self-assertion and control that he sees as driving politics.

So, it looks like we have two quite opposed orientations on the table. While both see themselves as resisting neoliberalism, populism sees the people taking back control of politics from the global economy and returning it to its rightful home in the nation while global justice envisions another world that benefits the worst off everywhere. What's more, each sees the other as creating obstacles 
to achieving real change. Should we try to adjudicate between them and take sides? Seek a synthesis? After all, on most academic definitions of populism, transnational populism is conceptually possible, if tricky in practice (De Cleen et alia, 2020; Ingram, 2019; Moffitt, 2017 and, in this volume, Kuyper and Moffitt, 2020). What I'd like to suggest, though, is that both orientations actually suffer from the same flaw: both treat neoliberalism as simply the contemporary expression of market fundamentalism. Implicit in both stories that I've told so far is an assumption that, in theory, neoliberalism is entirely concerned with holding up the market as the highest form of human organization and, in practice, flattens and homogenizes the world by turning us all into functionally identical instances of homo economicus. But neoliberalism is more than this caricature suggests; it has a political theory of the state, the family, and the self and, as a politics, it gives ordinary people compelling ways of understanding those things. Failure to reckon with this distorts the analysis of both populism and global justice in ways that the other can identify but cannot correct.

To the extent left populists like Mouffe want to break with neoliberalism, they need to reckon with the ways that neoliberalism does not just break down political and social hierarchies, but also relies on and sustains them. Otherwise, they will find that assertions of sovereignty do more to reinforce neoliberalism and reproduce its hierarchies than to resist them. And to the extent left populism overlooks the way neoliberalism relies on hierarchies of race and gender in its quest to unify the people, it will often entrench those forms of exclusion and exploitation that it putatively opposes. Unfortunately, the global justice literature is rarely in a position to make this point because while its philosophical framework rejects unjustified hierarchies, it often lacks a welldeveloped account of why people nevertheless feel invested in and attached to hierarchies that disadvantage them. That is, global justice - and the egalitarian liberal literature that it is often grounded in - offers a well-developed account of why our present circumstances are unjust, but not how they are sustained. As a result, global justice often talks about what people should do or what it would be right to do, but not about how they feel or about how those feelings shape their understanding of their interests. This leaves it open to populist criticisms that position cosmopolitan concern as an elite privilege and suggest ordinary people can't be motivated to care about those who aren't co-nationals (a notable exception here is effective altruism, which explicitly thinks about how to motivate people but which is not concerned with equality). This is characteristic of the way that many theorists of global justice fail to recognize that their philosophizing can itself be understood as a political practice and, if they intend to realize their ideals, can and should be judged by the standards 
appropriate to political action. In short, both the populism and global justice literatures need to reconsider their organizing frameworks if they are to help us resist neoliberal inequality.

\section{Neoliberal Inequalities}

Before I continue, let me explain what I mean by neoliberalism in more detail. Drawing from political theorists like Wendy Brown, geographers like David Harvey, and intellectual historians like Angus Burgin - all themselves building on Michel Foucault's 1979 lectures - I understand neoliberalism as a political theory developed by thinkers like Friedrich Hayek and Milton Friedman that grounds the legitimacy of the state in its capacity to create and maintain efficient markets (Brown, 2015; Harvey, 2007; Burgin, 2012; Foucault, 2010). This theory is taken up by politicians to justify policies like cutting taxes on the wealthy and rolling back the welfare state. But it's also taken up by ordinary people to make sense of their everyday lives; within a world that not only holds up the market as indispensable but requires participation in it to live, people predictably begin to employ the competitive order to frame their understanding of and decision-making in the world more generally.

Mouffe speaks for many when she describes neoliberalism as 'a whole conception of society and of the individual grounded on a philosophy of possessive individualism' (2018: 12). This interpretation seems well supported if we look at key neoliberal thinkers. Friedman refers to society as 'a collection of Robinson Crusoes' (2002: 13) while Hayek argues,

'A Great Society has nothing to do with, and is in fact irreconcilable with "solidarity" in the true sense of unitedness in the pursuit of known common goals. If we all occasionally feel that it is a good thing to have a common purpose with our fellows, and enjoy a sense of elation when we can act as members of a group aiming at common ends, this is an instinct which we have inherited from tribal society' (1978: 111).

On this interpretation, neoliberalism is like an acid that dissolves everything into individual contracts, first in ideology and then, as it achieves political hegemony, in the world itself. All freedom becomes, in the words of Eric MacGilvray, market freedom (2012: 141-146). The social relations that result, while formally free and equal, predictably feature great material inequality. Hayek himself highlights how thin freedom and equality are on the neoliberal view when he writes, 'Even if the threat of starvation to me and perhaps to my family impels me to accept a distasteful job at a very low wage [...] I am not coerced' (1960: 137). 
On this interpretation, neoliberalism seeks to produce a homogenized world of atomized individuals in which, as Foucault puts it, 'the worker himself appears as a sort of enterprise for himself' (2010: 225). While such individuals inhabit a world of unequal circumstances, the individuals themselves are functionally interchangeable. In part because of this, Nancy Fraser presents neoliberalism as a natural ally of a kind of progressivism (Fraser, 2013). Hierarchies of race and gender seem to have no place in a world where irrational prejudices against prospective employees and customers make you inefficient and likely to be outcompeted; as Milton Friedman puts it, 'a free market separates economic efficiency from irrelevant characteristics' $(2002,109)$. What's more, anyone can be an entrepreneur - because, after all, everyone has to be an entrepreneur which means that new opportunities for material success have opened up to those who are willing to lean in.

This is a picture in which the only hierarchies within neoliberalism are material inequalities, which means that all populists or global justice advocates need to do to resist neoliberalism is unify the great majority of people who are on the wrong end of those inequalities. Unfortunately, as I will argue, this picture of neoliberalism is misleading because of what it omits; as a result, a politics that operates with this picture will end up reproducing the hierarchies internal to neoliberalism that it ignores. In fact, resisting neoliberal inequality requires reckoning with its entanglement with sovereignty, race, and gender.

Let me start with the political hierarchies internal to neoliberalism, which I will argue make the populist invocations of popular sovereignty much less oppositional than they imagine. In his 1951 article 'Neoliberalism and Its Prospects,' Milton Friedman explained what distinguished neoliberalism from nineteenth-century laissez-faire - that is, what was new in neoliberalism. Laissez-faire, he wrote, 'failed to see that there were some functions the price system could not perform and that unless these other functions were somehow provided for, the price system could not discharge effectively the tasks for which it is admirably fitted' (1951: 3). Instead, he said, in what he called this 'new faith,' the state would have an active role, 'providing a framework within which free competition could flourish and the price system operate effectively' (ibid.: 3). Central to that active role is the state's coercive capacity to enforce rules and punish rulebreakers. In New York Times columnist Thomas Friedman's concise formulation, 'The hidden hand of the market will never work without a hidden fist' (Friedman, 1999). For neoliberalism, the market and the prison are intrinsically related; other government functions, like welfare provision, can and should be taken over by the market but what ultimately justifies the state is its power to discipline, punish, and police (Gill, 1995; Passavant, 2005). 
The neoliberal view of the state is thus not at all one of simple opposition. As Thomas Biebricher puts it his book The Political Theory of Neoliberalism, 'The strategic centrality of the state to neoliberal theory and practice derives from its very ambivalence, since it is, simultaneously, the crucial instrument in creating the conditions for functioning markets, but also, arguably, the greatest threat to them' (2019: 33; emphasis original). For neoliberals, a small, weak government isn't inherently desirable because it may need to be quite strong to carry out its proper function in some cases; it's essential that political institutions work to 'encase' markets, in Quinn Slobodian's phrase (2018: 7), but other functions are inessential or even illegitimate. Recognizing this, some left populists interpret organizations like the EU as a neoliberal encasement of the market and see assertions of national popular sovereignty as a way to break the state out of this constraint and use it for their own redistributive ends. Against EU optimists like Habermas, who see an opportunity to repurpose international organizations to create a transnational polity, proponents of Lexit and likeminded Euro-skeptics of the left see constraints on state action as undemocratic on their face.

But populist claims to unconstrained popular sovereignty are not always a meaningful way of repoliticizing markets when those claims employ antiinstitutional and anti-pluralist logics that are shared with neoliberalism. The earlier objections to Tuck's argument that I raised from the perspective of global justice were philosophical; they concerned the rational justification for sovereignty. The objections I want to consider now are political; they are about how populist claims circulate. First, as Nadia Urbinati has argued, populist claims to popular sovereignty often rest on discrediting existing representative institutions as irrelevant to political will-formation (Urbinati, 2013). If those institutions were properly functioning, this populist story goes, then the people would already be effectively represented and the populist movement would not need to make a claim to represent the people's will directly. But in identifying themselves rather than the outcome of complex institutional processes as the authentic voice of the people, these populists suggest that really existing political institutions are, in effect, not properly political but more like inauthentic bureaucracies.

For this populism, as for neoliberalism, government should be a tool for realizing a vision that has already been decided. Thus, for rightwing populists, their claims of exclusive legitimate representation of the people work handin-hand with neoliberal encasement, which likewise suggests a wide range of government actions are illegitimate and outside the proper domain of the political. Such populism works with neoliberalism to delegitimize government action as the work of elitist bureaucrats and planners engaged in inappropriate 
social engineering that usurps the choices of ordinary people (Davies, 2019: 26-27). And if neoliberal encasement creates a democratic deficit, rightwing populism can step into the fill the gap, since it portrays its endorsement of austerity as an expression of popular sovereignty. But there is no symmetrical affinity between popular sovereignty and anti-institutionalism on the populist left, which seeks to expand the domain of the political to include the market even as it also sets itself the task of narrowing the political by showing why purportedly representative institutions are inauthentic. For example, Tuck (2016) argues that the EU would have prevented the creation of the National Health Service, suggesting that for left populists, government bureaucracy is not a problem when they're our bureaucrats. That's not a philosophically incoherent position, but it lacks the political advantages that now accrue to rightwing uses of the claim; in the context of neoliberal hegemony, it can be challenging to delegitimize representative institutions in a way that doesn't reinforce prevailing neoliberal skepticism about public life.

Moreover, the left populist focus on expressions of popular sovereignty as a form of resistance to neoliberal encasement in the EU, the WTO, and elsewhere tends to overrate the importance of neoliberal encasement and underestimate the ordinary democratic endorsement of neoliberal policies. As Nicholas Mulder (2019), among others, has argued, these transnational institutions are not just impositions on top of states, but have taken the shape they did because they are the product of cooperation among liberal democratic governments that were elected and re-elected, often not in spite of these policies but because of them. A focus on popular sovereignty as the central means to resist the foreign imposition of EU rules can become a way of excusing the actually-existing people from having voted for and supported neoliberal policies. I'll return to this point about the importance of acknowledging the genuine appeal of neoliberalism in my conclusion since I think it's one that critics of neoliberalism too often overlook.

\section{Political Logics of Pluralism}

For now, I want to turn to another way in which populist claims to popular sovereignty can reinforce neoliberal hierarchies - their anti-pluralist conception of the people who are sovereign. It's safe to say that there is an emerging consensus in populist studies that populism is anti-pluralist. In their representative introduction to populism, Cas Mudde and Cristóbal Rovira Kaltwasser argue that populism conceives of the people as 'homogenous' and assert 'there are at least two direct opposites of populism: elitism and pluralism' (2017: 6-7). ${ }^{3}$ I think we find the same claim about difference as an obstacle to unity in Ernesto Laclau's theory of populism and while Jan-Werner Müller

3 They are here drawing directly from Mudde 2004. 
disputes the idea that populism is anti-elitism, he agrees it is anti-pluralist (Müller, 2016; Laclau, 2005). For my own part, I don't think that populism is necessarily antipluralist, but it is indisputable that much populism is in fact antipluralist and often avowedly so (McKean 2020).

Now, we should distinguish two kinds of pluralism that are related but distinct. The first is interest group pluralism, which sees politics as fundamentally concerned with balancing the interests of competing organized groups. I'll call the second identity pluralism, which avows the importance and non-substitutability of identities connected to race, gender, sexuality, and other significant features of individuals. These two kinds of pluralism are importantly connected; identitybased groups often have interest groups and lobbies to represent them, as the NAACP claims to represents African-Americans, the Human Rights Campaign claims to represents members of the LGBTQ community, and so on. But they're distinct in that the first locates pluralism on the level of political organization while the second concerns the groups individuals identify with.

Interest group pluralism clearly runs contrary to populism because it not only resists the unity of the people but is also usually an elite-centered view of politics as driven by group leaders brokering deals. Importantly, neoliberalism also rejects interest group pluralism, seeing such groups as lobbies liable to engage in market-distorting rent-seeking. For example, the ordo-liberal Alexander Rüstow explicitly denounced the 'pathological form of government... of pluralism' and it is easy to see echo of this complaint in contemporary attacks on 'special interests' (1942: 277, cited in Biebricher 2019: 86). So we see an important point of contact between populism and neoliberalism here.

Even though it is continuous with neoliberalism on this point, I think populism's rejection of interest group pluralism helps explain why populism feels like a break with the recent past - but as Aziz Rana (2018) has argued, this is a break not with neoliberalism, but with Cold War liberalism. It was Cold War liberalism that developed a sophisticated defense of interest group pluralism as a mode of politics. In competition with the Soviet Union, Cold War liberals legitimated US hegemony with a vision of the world as divided by ideological competition; that vision justified expansive international engagement and put some pressure on the US to improve its own civil rights record even as it also furiously marginalized and repressed left movements. Contemporary populists do clearly break with this legacy: they stand in a much more ambiguous relationship to ideology; they question the importance of the global as a frame of reference; and they reject the liberal decorum that places political importance on how one's domestic politics appear to others. It is populism's breaks with 
Cold War liberalism that have framed many of the recent books expressing concern about declining democratic norms, which have largely not considered Cold War liberalism's own democratic deficiencies.

Matters are somewhat different with identity pluralism. Much rightwing populism explicitly constructs a political identity in opposition to what it pejoratively calls 'identity politics' and positions itself as speaking authentically against the strictures of 'political correctness.' But we also often see left populism that rejects identity politics as an obstacle to the unitary people it wants to construct. For example, in criticizing the EU as undemocratic, Thomas Fazi, co-author of Reclaiming the State: A Progressive Vision of Sovereignty for a Post-Neoliberal World, singles out heterogeneity as a political obstacle, claiming that 'democracy presupposes the existence of...a political community, usually (though not exclusively) defined by a shared and relatively homogenous language, culture, history, normative system, etc.' (Fazi, 2019; see also Fazi, 2017). When assertions of popular sovereignty are based on such an antipluralist view of the people, then it should not surprise us to find not only immigrants but all those marked as different excluded or assigned to a subordinate position in politics.

Some on the left see opposition to identity pluralism as a means of resisting neoliberalism because, as I've already mentioned, neoliberalism can adopt a progressive face. It can position itself as an inclusive force welcoming of heterogeneity precisely because of its individualism; Foucault famously imagined the possibility of neoliberalism as 'an optimization of systems of difference, in which the field is left open to fluctuating processes, in which minority individuals and practices are tolerated' (2010: 259-260). But egalitarians and others on the left make a serious mistake if they take this tolerant view at face value and oppose identity pluralism because neoliberal seems to embrace it or because they think it is simply an obstacle to addressing economic inequality.

What neoliberalism embraces, after all, is not the right to be who you are, but the right to be who the market will bear. And since neoliberalism affirms the necessity of inequality as the result of efficient markets, the differences that neoliberalism seeks to optimize are above all hierarchical and optimizing reproduces that hierarchy of difference. For Milton Friedman, for example, the optimization of difference meant not racial integration but racial segregation, at least in the short run. In Capitalism and Freedom, Friedman writes,

'The man who exercises discrimination pays a price for doing so. He is, as it were, "buying" what he regards as a "product." It is hard to see that discrimination can have any meaning other than a "taste" of others that one does not share' (2002: 110). 
Having framed racial oppression as a matter of white people's taste that can be priced on the market, Friedman continues,

'Is there any difference in principle between the taste that leads a householder to prefer an attractive servant to an ugly one and the taste that leads another to prefer a Negro to a white or a white to a Negro, except that we sympathize and agree with the one taste and may not with the other?' (ibid.).

What's salient here is not Friedman's personal racism or sexism - in this passage, he goes on to explicitly disavow the 'taste' for discrimination - but the way neoliberalism can remain formally open to difference and diversity on the level of the individual while structurally reinforcing and reproducing inequality. From the perspective of market freedom, a white person's taste for white supremacy is functionally identical to an African-American's taste for equal treatment.

The treatment of these as matters of individual taste thus obscures the history and social structures that sustain persistent racial inequality once formal legal equality has been achieved. And from the neoliberal perspective, once formal legal equality has been achieved, no further government action to coercively integrate neighborhoods or to redistribute wealth to bridge the racial wealth gap is appropriate (except insofar as justified by the aim of market efficiency). Friedman writes,

'in a society based on free discussion, the appropriate recourse is for me to seek to persuade them that their tastes are bad and that they should change their views and their behavior, not to use coercive power to enforce my tastes and my attitudes on others' (2002: 111).

In other words, while Friedman expressed hope that whites could be persuaded to abandon white supremacy, he also recognized that segregation can be optimal from the perspective of the competitive order since it simply reflects the fact that whites have access to greater resources and are willing to use those resources to the pay the 'price' of maintaining segregation. Of course, here it matters which white people we're talking about; while some firms may succeed by exploiting inefficiencies and embracing diversity, the continued oppression of African-Americans as a group benefits employers generally since it creates a segmented labor market with a class of low wage labor that creates pressure to keep others' labor costs low. The same is true for undocumented immigrant workers; their lack of legal protections creates a vulnerable class of exploitable workers that can be used to undercut the wages of others (Dias-Abey, 2019; Valdez, 2019; Ypi; 2019). 
For those concerned with resisting neoliberalism, opposing identity pluralism does nothing to address these inequalities, but can make them harder to alleviate since targeted programs that benefit minority populations highlight the heterogeneity of the people, not their unity. Indeed, when wed to antipluralism, strengthening the legitimacy of the state's coercive power by associating its police powers with popular sovereignty risks legitimating the use of this power against those who are already marginal - particularly, those who do not fit the populist conception of the people. As a result, left populists sometimes end up offering a politics that is structurally anti-immigrant despite their avowed intentions. For example, Mouffe explicitly suggests 'Identifying as citizens whose political objective is the radicalization of democracy is what would unite social agents' (2018: 66), but this already takes it for granted that non-citizen immigrants have no place even in a radical democracy. ${ }^{4}$

However, rather than acknowledge this exclusion as a political judgment, Mouffe naturalizes it. Mouffe recognizes the political nature of neoliberalism's engagement with our emotions, writing, 'To maintain its hegemony, the neoliberal system needs to constantly mobilize people's desires and shape their identities' (2018: 77). But when it comes to emotional attachment to the nation, rather than recognizing it as an affect that politics can produce or mobilize, she naturalizes nationalism, writing, 'a left populist strategy cannot ignore the strong libidinal investment at work in national - or regional - forms of identification' (ibid.: 71). In doing this, she posits this 'libidinal investment' as though it is a fixed point in politics, overlooking the ways effects of nationalism are also reproduced by neoliberal politics. For one thing, while they agree on the need to constrain the state and encase the market, neoliberals themselves differ about the appropriate way to do so, with many opposing the EU precisely because they think any transnational federation is too pluralist - and because this one effectively locked in too many social welfare policies (Slobodian and Plehwe, 2018). But more broadly, we often find neoliberals championing national identity precisely because it so often can trump other forms of identity, like class, that are more incompatible with the vision of a society of entrepreneurs they promote.

That the populist insistence on popular sovereignty often aligns closely with neoliberalism can be seen clearly from the perspective of the global economy. Globally, neoliberalism has exploited the poverty of developing nations through the imposition of neoliberal austerity and export-oriented development through

4 Mouffe's view similarly has no space for indigenous people, whose claims to sovereignty often conflict with the majority's. Strikingly, she says that a 'properly political way' of looking at the struggle for hegemony between left and right populism is as a 'frontier,' a metaphor whose power is inextricable from settler colonialism (2018: 84-85). See Singh 2019. 


\section{POPULISM AND GLOBAL JUSTICE:}

A SIBLING RIVALRY?

the IMF and World Bank's structural adjustment programs. As a result, these countries are introduced to economic interdependence on unfavorable terms; the prices of their agricultural products are at the mercy of a global market full of speculators and sweatshop production in apparel, electronics, and other industries can move if wages threaten to rise too much. From this perspective, the idea that what the US and Europe need is more forceful expressions of sovereignty to take back control looks absurd (Koram, 2019). It looks, in fact, a lot like the claim that white men are anxious about the loss of privileged status that comes from progress towards race and gender equality (Valdez, n.d.).

My point here is not simply to reiterate the global justice claim that the global distribution of wealth is unjustifiable, but that both left and right populism are imbricated with neoliberalism, which means that appealing to populism as a rejection of neoliberalism can't be the whole story. Nancy Fraser plausibly argues that neoliberalism is 'a political-economic project that can articulate with several different and even competing projects of recognition - including progressive ones,' but more controversially adds that 'neoliberalism had most durably articulated with progressivism' (2019: 42-3). This claim overlooks that neoliberalism is actually most often articulated with a defense of traditional hierarchies, either through explicit social conservativism or through a reactionary populism that seeks to put women and minorities in their place. Because she associates neoliberalism more durably with progressivism, Fraser explicitly says Steve Bannon put forward a 'pro-working class populism' (2019: 52) that represented an alternative to neoliberalism. ${ }^{5}$ For all the reasons I've already explained, I think seeing Bannonism or Trumpism as an alternative to neoliberalism is a big mistake; if anything, it is better understood on the model of a populist neo-illiberalism (Hendrikse, 2018). What Quinn Slobodian has written about Germany and Austria applies more broadly:

'Contemporary right-wing populism in Germany and Austria emerged within neoliberalism, not in opposition to it. This is not the wholesale rejection of globalism but a variety of it, one that accepts an international division of labor with robust cross-border flows of goods and even multilateral trade agreements while tightening controls on certain kinds of migration' (Slobodian, 2018b).

In other words, both contemporary populists and global justice advocates accept a global framework; the question is, what ways of dividing up the world do we think are most politically salient? Should the US working class identify with a national sovereignty that uniquely binds them in community with US

5 None of this is meant to deny the existence of neoliberal feminism. See Rottenberg (2014). 
elites rather than with the working classes of other countries? While populists argue that such national identification is political common sense, are global justice advocates in a position to offer a different mode of affective political engagement?

\section{Emotional Investments in Neoliberalism}

A fuller understanding of neoliberalism grasps the way that it not only reproduces hierarchies and inequalities, but produces affective investments in them. Fraser's analysis assumes the view of neoliberalism as corrosive of all social ties; from the feminist perspective Fraser examines, that gives neoliberalism an emancipatory sheen since it frees women to enter the market and support themselves rather than providing care to family members and being dependent on a husband. But if we look at the words of neoliberals themselves, we find something else. Milton Friedman is clear: 'The ultimate operative unit in our society is the family, not the individual' (2002: 33). ${ }^{6}$ In fact, the earlier line I gave you about Robinson Crusoe was misleading; here's the full sentence: 'society consists of a number of independent households - a collection of Robinson Crusoes, as it were. Each household uses the resources it controls to produce goods and services that it exchanges for goods and services produced by other households...' (2002: 13). And we find the same among neoliberal politicians; as Margaret Thatcher famously said in 1987, 'who is society? There is no such thing! There are individual men and women and there are families' (McSmith, 2010: 297; emphasis mine).

This centrality of the family is not idiosyncratic or ad hoc, but as Melinda Cooper (2017) has argued, fully developed as the ground of an argument for the rollback of the welfare state, which is interpreted as crowding out the family. For example, Friedman used the centrality of the family to argue that before Social Security, 'Children helped their parents out of love or duty. They now contribute to the support of someone else's parents out of compulsion and fear. The earlier transfers strengthened the bonds of the family; the compulsory transfers weakened them' (1980: 106). In this conception of the family, we see how neoliberalism is not simply corrosive of social ties, but relies on and valorizes some forms of solidarity as essential to the functioning of markets. To the extent left populists continue to understand neoliberalism as purely corrosive of family ties, shoring up such social solidarity will wrongly appear as a form of resistance to neoliberalism. But as Cooper argues, 'leftist demands for the decommodification of social life or the protection of kinship relations all too readily lend themselves to the social conservative argument that certain forms of (domestic, feminized) labor should remain unpaid' (2017: 23).

6 We find similar claims in Hayek. In The Constitution of Liberty, he writes, 'society is made up as much of families as of individuals [...] the transmission of the heritage of civilization within the family is as important a tool in man's striving toward better things as is the heredity of beneficial physical attributes' (1960: 90). 
As we saw with race, this perspective allows us to see that the relationship between populism and neoliberalism with respect to gender is not necessarily one of opposition. Of course, the relationship between populism and gender is itself contested; in a recent survey of work on the topic, Mudde and Kaltwasser concede that populist parties tend to attract disproportionate support from men, but conclude 'Both in theory and practice, populists do not hold a strong position on gender issues' (2015: 35; see also Abi-Hassan, 2017). On the other end of the spectrum, Akwugo Emejulu argues,

'populism is poison for feminist politics [...] Its discursive construction of a homogenised and reified "people," its promotion of a crude majoritarianism, and its (mostly) uncritical support for popular belief systems, means that it is incredibly difficult to build feminist politics and a feminist collective identity with and through traditional populist practices' (2017: 63; see also Geva, 2020).

Defenders of populism may find Emejulu's point overstated, but an antipluralist populism will surely have trouble promoting feminist policies that are justified by reference to women's interests specifically rather than the people's common good.

Again, we see an asymmetry in populism's political relation to neoliberalism: rightwing populist invocations of women's special role in the family face no such obstacles because the family is already positioned as essential to the market and thus to the common good. Let's go back to the Polish teacher's strike I mentioned earlier. At the same time that the government was refusing to improve teacher salaries, it was also expanding its program that offers monthly cash payments to families for having more kids (Cragg, 2019). The president's chief-of-staff rebuked the teachers by saying that if they wanted more money, they should get pregnant; 'Teachers are not obliged to live in celibacy,' he said (Santora and Berendt, 2019). As we can now see, this is perfectly comprehensible from the perspective of both neoliberalism and rightwing populism. To the extent that left populism relies on anti-pluralist popular sovereignty as its political lodestar, it is not well placed to respond. A left populism that rejects antipluralism would still be a politics that pits ordinary people against corrupt elites, but it may look quite different in other respects; a pluralist left populism may find it easier to envision a transnational people who can contest neoliberalism across borders, for example.

Global justice too would need to be transformed to contribute to such a political project. In some respects, global justice advocates are better placed to resist the neoliberal reliance on patriarchal family structures. While often grounded 
in the egalitarian liberalism of John Rawls, many global justice theorists have moved beyond Rawls's own relative inattention to the family. ${ }^{7}$ Theorists like Iris Marion Young and Alison Jaggar have critiqued neoliberalism for intensifying gendered vulnerability, as the rollback of the welfare state has shifted greater responsibilities for unwaged carework onto women even as it has also increased their need to enter the market to earn an income. Among women who can afford to pay someone else to help with carework, this creates a demand for nannies and those nannies must then in turn hire even more poorly-paid women to help care for the families they leave at home in order to earn an income. In Jaggar's words, 'women's cheap domestic labor underwrites the entire global economy' (2009: 42; see also Tronto, 2011).

But while this analysis provides an incisive critique of the injustice of these arrangements, it lacks an account of how people nevertheless remain invested in them. If we no longer see neoliberalism as simply corrosive but also producing its own affective ties, we can't simply decry it for undoing the welfare state but also need to develop critiques of the attitudes associated with neoliberalism. We've already seen how, from the perspective of populism, a demand for global justice can seem inert or even elitist when it is formulated to be objective, a truth outside politics and disconnected from the experiences and interests of ordinary people today. Avoiding this charge requires global justice advocates not only to think of their own theoretical reflections as embedded within politics, but also to think about how to connect their demands for justice to the way people experience neoliberalism. Under neoliberalism, institutions are structured so that those subject to them are habituated to perceive life as a competitive order. How can advocates for global justice move people to see and feel otherwise? This pushes global justice in a direction that the egalitarian liberal tradition has historically been reluctant to go, both because of its focus on institutional principles of justice and because of concerns that attaching political obligations to people's attitudes and emotions violate their right to privacy. But I don't see any way to avoid this if egalitarians are to respond to the challenge of neoliberalism.

Consider the politics of anxiety. Populism is very often framed as a response to anxiety, typically economic anxiety about one's own precarious circumstances. Many suggest that neoliberalism directly causes these anxieties through the economic conditions it creates, thereby bringing about a populist countermovement along the lines suggested by Karl Polanyi. This is the implicit framing of a recent New York Times article titled 'With His Job Gone, an Autoworker Wonders, "What Am I as a Man?", which poses the reassertion

7 Martha Nussbaum made explicit the neoliberal resonance of Rawls's assumptions about the family, writing, 'Rawls adopted a strategy similar to that of economist Gary Becker when he assumed that the head of the household is a beneficent altruist who will adequately take thought for the interests of all family members' (1999: 65). 
of male authority as a natural response to economic dispossession (Tavernise, 2019). But it's notable that there is scant evidence that economic hardship or precarity predicts support for contemporary populist parties (just on the US context, see Green and McElwee, 2019; Reny et alia, 2019; Sides et al, 2018). Others suggest we understand this underlying anxiety as concerning social changes beyond one's control; recall Richard Tuck and Christopher Bickerton avowing fear as the motive for populism, the fear that came from knowing we couldn't shut our borders even if we wanted to. This claim seems more plausible in the context of the European refugee crisis beginning in 2015 than it does in the US context, where Trump made the US/Mexico border a hugely salient issue despite a decade-long decline in unauthorized immigration (Passl and Cohn, 2018).

Setting that aside, I think many people intuitively support the claim that neoliberalism causes anxiety because it puts things in the hands of the market and takes them out of our control. Yet this is hardly distinctive to neoliberalism. Neoliberalism is not the first modality of capitalism to do this and it is questionable if any social system can offer the kind of control that Tuck and Bickerton claim people yearn for. What's more, neoliberals themselves were well aware that the kind of world they were trying to create could be difficult to navigate and did not leave this problem entirely unaddressed. Neoliberalism can actually be seen to soothe anxiety by offering a 'sociodicy' which explains why market forces necessarily produce the best possible results, despite the fact that no particular outcome can ever be predicted (Bourdieu, 1998). In the US context in particular, this sociodicy powerfully attaches to religious theodicy, creating an even greater capacity to rationalize and be reconciled to economic outcomes (Moreton, 2010; Spence, 2016; Sullivan and Delaney, 2017). And even as neoliberalism provides an explanation for why things have turned out as they did, it also provides sources of hope for the future. To imagine myself as an entrepreneur, to think of my actions as investment in my own human capital, means that my laboring is constitutively future-oriented, no matter how tedious it is. The meaning of my work isn't defined by the present but by its uncertain future rewards, which are mine to imagine. All of this means that seeing neoliberalism solely as a source of anxiety impairs egalitarians' responses to it. In particular, it suggests that one potentially attractive way to cope with neoliberalism is to lean into its promises and hopes even more fully.

Of course, neoliberalism's capacity to soothe anxiety is uneven and imperfect. This is indeed part of what creates political possibility: neoliberal theory and neoliberal practice do not always go hand in hand. And we can understand this 
gap as itself a cause of an anxiety that could be politically productive if we can take advantage of it. Raymond Williams wrote:

'There is frequent tension between the received interpretation and practical experience. Where this tension can be made direct and explicit, or where some alternative interpretation is available, we are still within a dimension of relatively fixed forms. But the tension is as often an unease, a stress, a displacement, a latency: the moment of conscious comparison not yet come, often not even coming' (1977: 130).

Williams suggested these 'structures of feeling' were widespread, politically significant forms of experience; while everyone's life has different details, their experiences can be understood as belonging to the same genre. Recently, Lauren Berlant took up Williams' work and suggested that the primary genre of experience under neoliberalism is the impasse, the feeling of being stuck when simply getting through the day feeling like a real accomplishment (2011: 4). I think the anxiety we experience today reflects the fact that, for good or ill, this impasse may be coming to an end - a sense that we don't know how the gap between neoliberal theory and practice will be closed. For all the reasons I've described, if either populism or global justice hope to exploit that gap to advance an egalitarian politics, they need to reckon more carefully with the way they are themselves entangled with neoliberalism's hopes and hierarchies. ${ }^{8}$

\footnotetext{
Benjamin McKean

Associate Professor

Department of Political Science

Ohio State University

email:mckean.41@osu.edu
}

\section{the globaljusticenetwork}

8 The author thanks Miriam Ronzoni and Tiziana Torresi for organizing the workshop where this paper was originally presented and for all their subsequent work and feedback as editors. The paper also benefited from discussion with Shannon Winnubst as well as audiences at Ohio State University's Political Theory Workshop, the American Political Science Association, and the International Political Science Association's “Socialism After Populism” conference at UC Riverside. 


\section{Bibliography}

Abi-Hassan S (2019) Populism and Gender. In: Kaltwasser CR, Taggart P, Ochoa Espejo P, Ostiguy P (eds) The Oxford Handbook of Populism. New York: Oxford University Press: 426444 .

Berlant L (2011) Cruel Optimism. Durham, NC: Duke University Press.

Bickerton C and Tuck R (2017) A Brexit Proposal. In: The Current Moment. Available at: https://thecurrentmoment.files.wordpress.com/2017/11/brexit-proposal-20-nov-final1.pdf (accessed 7 July 2018).

Biebricher T (2019) The Political Theory of Neoliberalism. Stanford, CA: Stanford University Press.

Bourdieu P (1998) The 'Globalization' Myth and the European Welfare State. In: Nice R (trans) Acts of Resistance. New York: The New Press.

Brown W (2015) Undoing the Demos: Neoliberalism's Stealth Revolution. Brooklyn, NY: Zone Books.

Burgin A (2012) The Great Persuasion: Reinventing Free Markets Since the Depression. Cambridge, MA: Harvard University Press.

Cragg G (2019) Poland woos voters with controversial child benefit scheme. France24. Available at: https://www.france24.com/en/20190507-poland-woos-voters-controversial-child-benefitsscheme-european-union (accessed 17 May 2019).

Crouch C (2004) Post-democracy. Cambridge, UK: Polity.

Cooper M (2017) Family Values: Between Neoliberalism and the New Social Conservatism. Brooklyn, NY: Zone Books.

Davies W (2019) Nervous States: Democracy and the Decline of Reason. New York: WW Norton.

De Cleen B, Moffitt B, Panayotu P, and Stavrakakis Y (2020) The Potentials and Difficulties of Transnational Populism: The Case of the Democracy in Europe Movement 2025 (DiEM25). Political Studies 68/1: 146-166.

Desmoulières RB (2017) Chantal Mouffe, the philosopher who inspires Jean-Luc Mélenchon. Verso Blog. Available at: https://www.versobooks.com/blogs/3037-chantal-mouffe-thephilosopher-who-inspires-jean-luc-melenchon (accessed 16 May 2019).

Dias-Abey M (2019) Left Nationalism and Labour Migration: A Law and Political Economy Perspective. Futures of Work. Available at: https://futuresofwork.co.uk/2019/05/24/leftnationalism-and-labour-migration-a-law-and-political-economy-perspective/ (accessed 25 May 2019).

Emejulu A (2017) Towards a Populist Feminism: Can Feminism for the 99\% succeed as a new kind of populism? Soundings: a journal of politics and culture 66: 63-67.

Fazi T (2017) Reclaiming the State: A Progressive Vision of Sovereignty for a Post-Neoliberal World. Chicago: Pluto Press. 
Fazi T (2019) The European Union Is an Antidemocratic Disgrace. Jacobin. Available at: https://jacobinmag.com/2019/o5/european-union-parliament-elections-antidemocratic/ (accessed 24 May 2019).

Foucault M (2010) The Birth of Biopolitics: Lectures at the Collège de France, 1978-1979. In Senellart M (ed), Burchell G (trans). Picador: New York.

Fraser N (2013) Fortunes of Feminism: From State-Managed Capitalism to Neoliberal Crisis. New York: Verso.

Fraser N (2019) The Old is Dying and the New Cannot Be Born. New York: Verso.

Friedman M (2002, originally published 1962) Capitalism and Freedom. Chicago: University of Chicago Press.

Friedman M (1951) Neo-Liberalism and its Prospects. Farmand. Available at: https:// miltonfriedman.hoover.org/friedman_images/Collections/2016c21/Farmand_02_17_1951.pdf (accessed August 14 2018).

Friedman M and Friedman R (1980) Free to Choose: A Personal Statement. New York: Harcourt Brace Jovanovich.

Friedman T (1999) A Manifesto for the Fast World. New York Times. Available at: https://www. nytimes.com/1999/03/28/magazine/a-manifesto-for-the-fast-world.html (accessed 7 March 2019).

Gera V (2019) Polish teachers' strike shines light on country's divisions. Associated Press. Available at: https://www.apnews.com/af3b877c59644feo8a624f1a58doobb6 (accessed 28 May 2019).

Geva D (2020) Daughter, Mother, Captain: Marine Le Pen, Gender, and Populism in the French National Front. Social Politics: International Studies in Gender, State \& Society 27/1: 1-26.

Gill S (1995) Globalisation, Market Civilisation, and Disciplinary Neoliberalism. Millennium: Journal of International Studies 24/3: 399-423.

Golshan T (2019) Trump said he wouldn't cut Medicaid, Social Security, and Medicare: His 2020 budget cuts all 3. Vox. Available at: https://www.vox.com/policy-andpolitics/2019/3/12/18260271/trump-medicaid-social-security-medicare-budget-cuts (accessed 27 May 2019).

Green J and McElwee S (2019) The Differential Effects of Economic Conditions and Racial Attitudes in the Election of Donald Trump. Perspectives on Politics 17/2: 358-379.

Harvey D (2007) A Brief History of Neoliberalism. New York: Oxford University Press.

Hayek F (1982) Law, Legislation and Liberty, Volume 2: The Mirage of Social Justice. London: Routledge.

Hayek F (1960) The Constitution of Liberty. Chicago: University of Chicago Press.

Hendrikse R (2018) Neo-Illiberalism Geoforum 95: 169-172.

Ingram J (2019) Populism and Cosmopolitanism. In: Kaltwasser CR, Taggart P, Ochoa Espejo P, Ostiguy P (eds) The Oxford Handbook of Populism. New York: Oxford University Press:

644-66o. 


\section{POPULISM AND GLOBAL JUSTICE:}

A SIBLING RIVALRY?

Koram K (2019) Britain's Blindness: How did 'national liberation' become a rallying cry in what was once the world's largest empire?. Dissent. Available at: https://www.dissentmagazine.org/ online_articles/britains-brexit-blindness (accessed 7 February 2019).

Kuyper J and Moffitt B (2020) Transnational Populism, Democracy, and Justice. Global Justice: Theory Practice Rhetoric 12/2: 27-49

Jaggar A (2009) Transnational Cycles of Gendered Vulnerability: A Prologue to a Theory of Global Gender Justice. Philosophical Topics 37/2: 33-52.

Laclau E (2005) On Populist Reason. New York: Verso.

Lakner C and Milanovic B (2016) Global Income Distribution: From the Fall of the Berlin Wall to the Great Recession. The World Bank Economic Review 30/2: 203-232.

MacGilvray E (2011) The Invention of Market Freedom. New York: Cambridge University Press.

McKean B (2020) Populism, Pluralism, and the Ordinary. In: Ron A and Nadesan M (eds) Mapping Populism: Approaches and Methods. New York: Routledge: 85-95.

McSmith A (2010) No Such Thing as Society: Britain in the Turmoil of the 1980s. London: Constable.

Moffitt B (2017) Transnational Populism? Representative Claims, Media and the Difficulty of Constructing a Transnational 'People.' Javnost - The Public 24/4: 409-425.

Moreton B (2010) To Serve God and Wal-Mart: The Making of Christian Free Enterprise. Cambridge, MA: Harvard University Press.

Mouffe C (2018) For a Left Populism. New York: Verso, 2018.

Moyn S (2018) Not Enough: Human Rights in an Unequal World. Cambridge, MA: Harvard University Press.

Mudde C (2004) The Populist Zeitgeist Government and Opposition 39/4: 541-563.

Mudde C and Kaltwasser CR (2017) Populism: A Very Short Introduction. New York: Oxford University Press.

Mudde C and Kaltwasser CR (2015) Vox populi or vox masculini? Populism and gender in Northern Europe and South America Patterns of Prejudice 4/1-2: 16-36.

Mulder N (2019) The Origins of European Neoliberalism. N+1 Magazine. Available at: https:// nplusonemag.com/online-only/online-only/the-origins-of-european-neoliberalism/ (accessed 2 May 2019).

Müller JW (2016) What is Populism? Philadelphia: University of Pennsylvania Press.

Nussbaum M (1999) Sex and Social Justice. New York: Oxford University Press.

Okin S (1989) Justice, Gender, and the Family. New York: Basic Books.

Passavant, PA (2005) The Strong Neo-liberal State: Crime, Consumption, Governance. Theory \& Event 8/3. ISN: 1092-311X. Available at: https://www.muse.jhu.edu/article/187839 (accessed 12 October 2020). 
Passl JS and Cohn D (2018) U.S. Unauthorized Immigrant Total Dips to Lowest Level in a Decade. Pew Research Center. Available at: https://www.pewhispanic.org/2018/11/27/u-sunauthorized-immigrant-total-dips-to-lowest-level-in-a-decade/ (access 27 May 2019).

Puhl J (2018) Europe Has Run Out of Gas. Spiegel Online. Available at: https://www.spiegel.de/ international/europe/interview-with-polish-prime-minister-mateusz-morawiecki-a-1194264. html (accessed 28 May 2019).

Rana A (2018) Goodbye, Cold War. N+1 Magazine. Available at: https://nplusonemag.com/ issue-30/politics/goodbye-cold-war/ (accessed 3 May 2019).

Reny TT, Collingwood L, and Valenzuela AA (2019) Vote Switching in the 2016 Election: How Racial and Immigration Attitudes, not Economics, Explain Shifts in White Voting. Public Opinion Quarterly 83/1: 91-113.

Rottenberg C (2014) The Rise of Neoliberal Feminism. Cultural Studies 28/3: 418-437.

Rüstow A (1942) General Sociological Causes of the Economic Disintegration and Possibilities of Reconstruction. In Röpke W (ed) International Economic Disintegration. London: William, Hodge.

Sanders B (2016) Tweet: 8:01 PM - 1 May. Twitter. Available at: https://twitter.com/ berniesanders/status/726924424474042368 (accessed 4 June 2018).

Sanderson R (2019). Italian deputy PM Salvini lays out EU reform plan. Financial Times. Available at: https://www.ft.com/content/d1aaa4dc-789e-11e9-be7d-6d846537acab (accessed 28 May 2019).

Santora M and Berendt J (2019) Polish Teachers End Strike to Allow Exams but Tell Government It's Not Over. New York Times. Available at: https://www.nytimes. com/2019/04/26/world/europe/poland-teachers-strike.html (accessed 28 May 2019).

Seidelman J and Watkins J (2019) Trump meant the end of neoliberalism. What comes next? Salt Lake Tribune. Available at: https://www.sltrib.com/opinion/commentary/2019/05/26/ commentary-trump-meant/ (accessed 18 May 2019).

Sides J, Tesler M, and Vavreck V (2018) Identity Crisis: The 2016 Presidential Campaign and the Battle for the Meaning of America. Princeton, NJ: Princeton University Press.

Singh J (2019) Decolonizing radical democracy. Contemporary Political Theory 18/3: 331-356.

Slobodian Q (2018a) Globalists: The End of Empire and the Birth of Neoliberalism. Cambridge, MA: Harvard University Press.

Slobodian Q (2018b) Neoliberalism's Populist Bastards. Public Seminar. Available at: http:// www.publicseminar.org/2018/02/neoliberalisms-populist-bastards/ (accessed 25 May 2019).

Slobodian Q and Plehwe D (2018) The Neoliberals Who Opposed Europe. Brave New Europe. Available at: https://braveneweurope.com/quinn-slobodian-and-dieter-plehwe-the-neoliberalswho-opposed-europe (accessed 25 May 2019).

Spence L (2016) Knocking the Hustle: Against the Neoliberal Turn in Black Politics. Brooklyn, NY: Punctum Books.

Sullivan KR and Delaney H (2017) A Femininity That 'Giveth and Taketh Away': The Prosperity 
Gospel and Postfeminism in the Neoliberal Economy. Human Relations 70/7: 836-59.

Tavernise S (2019) With His Job Gone, an Autoworker Wonders, 'What Am I as a Man?'. New York Times Available at: https://www.nytimes.com/2019/05/27/us/auto-worker-jobs-lost.html (accessed May 27, 2019).

Tronto J (2011) A Feminist Democratic Ethics of Care and Global Care Workers: Citizenship and Responsibility. In Mahon R and Robinson F (eds) Feminist Ethics and Social Policy: Towards a New Global Political Economy of Care. Vancouver: University of British Columbia Press.

Trump D (2016) Declaring America's Economic Independence. Politico. Available at: https:// www.politico.com/story/2016/o6/full-transcript-trump-job-plan-speech-224891 (accessed 4 June 2018).

Tuck R (2016) Left Case for Brexit. Dissent Magazine. Available at: https://www. dissentmagazine.org/online_articles/left-case-brexit (accessed 7 July 2018).

Urbinati N (2013) The Populist Phenomenon. Raisons politique 3/51: 137-154.

Valdez I (2019) Beyond the Dream and Promise Act: Why Democrats must turn the immigrant labor narrative upside down. LSE US Centre American Politics and Policy Blog. Available at: https://blogs.lse.ac.uk/usappblog/2019/04/o8/beyond-the-dream-and-promise-act-whydemocrats-must-turn-the-immigrant-labor-narrative-upside-down/ (accessed 8 April 2019).

Valdez I (n.d.) Popular Sovereignty and Empire: Capitalism and the Problem of Self-and-Other Determination. (unpublished manuscript).

Williams R (1977) Marxism and Literature. New York: Oxford University Press.

Ypi L (2019) 'The secret by which the capitalist class maintains its power': the effect of antiimmigration rhetoric. LSE British Politics and Policy Blog. Available at: https://blogs.lse.ac.uk/ politicsandpolicy/the-effect-of-anti-immigration-rhetoric/ (accessed 12 April 2019). 